NBER WORKING PAPER SERIES

THE SOCIAL VERSUS THE PRIVATE INCENTIVE

TO BRING SUIT IN A COSTLY LEGAL SYSTEM

St even Shavell

Working Paper No. $\underline{741}$

NATIONAL BUREAU OF ECONOMIC RESEARCH

1050 Massachus etts Avenue

Cambridge MA 02138

Sept ember 1981

The research reported here is part of the NBER's research program in Law and Economics. Any opinions expressed are those of the author and not those of the National Bureau of Economic Research. 
The Social Versus the Private Incentive to Bring Suit in a Costly Legal System

\begin{abstract}
The question is asked how the incentives of private parties to bring suit relate to what would be socially appropriate given the costs of using the legal system; and the answer presented in the model that is examined involves two elements. The first is that as a potential plaintiff takes into account only his own legal expenses in deciding whether to bring suit, the private cost of suit is evidently less than the social cost (which would include the defendant's legal expenses), suggesting a tendency toward excessive litigation, other things equal. But consideration of the second element complicates matters: as the plaintiff takes into account his own expected gains but not the social gains attaching to suit (which in the model is the general effect of suit on potential defendants' behavior), and as these social gains could be either larger or smaller than his gains, there is a tendency in respect to litigation that could either counter or reinforce the previous tendency.
\end{abstract}

Professor Steven Shavell Harvard University

Law School

Langdell 260

Cambridge, Massachusetts 02138

(617) $495-7920$ 
The Social Versus the Private Incentive to Bring suit in a Costly Legal system

Steven Shavell*

How do the incentives of private parties to bring suit relate to what would be "socially appropriate." given the costs of using the legal system? This question will be considered in the present note employing a simple model according to which suit involves legal expenses, and the prospect of suit may encourage potential defendants to take actions that reduce the likelihood that they cause monetary losses for potential plaintiffs. ${ }^{1}$

To explain the answer to the question that will be presented in the model, let us compare on the one hand the private and social costs of suit, and on the other hard, the private and social benefits of suit.

The first of these comparisons is unambiguous in the model, for to a potential plaintiff ${ }^{2}$ the cost of bringing suit involves only his own legal expenses, whereas the social cost includes the defendant's legal expenses as well. ${ }^{3}$ Thus the private cost of suit is less than the social cost, suggesting a tendency toward excessive litigation, other things equal. 4

However, comparison of the private and social benefits of suit complicates matters. The private benefit of suit resides in the model in the payment that the plaintiff 
expects to receive from the defendant, but the social benefit of suit inheres in an "externality"--its effect on the behavior of potential defendants generally. ${ }^{5}$ There is no necessary connection between the private benefit of suit and this social benefit. It may be that the social benefit exceeds the private benefit; that is, suit may lead to a reduction in losses caused by potential defendants which is greater than a plaintiff's expected gains; or it may be that the opposite holds true (consider the extreme case where potential defendants have virtually no ability to reduce losses, so that suit would have virtually no effect on losses). ${ }^{6}$ In consequence, divergence between the social and private benefits of suit may result either in a tendency toward too little litigation (countering the previous tendency due to the divergence between social and private costs) or toward too much litigation (reinforcing the previous tendency).

After identifying the factors determining the social appropriateness of litigation in the model, two numerical examples will be discussed (to which readers who are not interested in the formal model may immediately turn), an extension of the model concerning settlement will be presented, and a concluding comment will be made.

1. The model ${ }^{7}$

It is assumed that parties are risk neutral; that defendants are able to reduce the probability that they cause losses by engaging in prevention activity; ${ }^{8}$ and that doing so involves costs. Specifically, define 


$$
\begin{aligned}
& \ell=\text { possible loss suffered by plaintiffs; } \ell>0 \text {; } \\
& \mathrm{p} \quad=\text { probability of loss if defendants do not } \\
& \text { engage in prevention activity; } p>0 \text {; } \\
& q \text { = probability of loss if defendants do engage } \\
& \text { in prevention activity; } p>q>0 \text {; } \\
& \mathbf{x}=\text { cost to a defendant of prevention activity. }
\end{aligned}
$$

If a defendant causes a loss and the plaintiff brings suit, he will obtain $\ell$ in damages from the defendant. ${ }^{9}$ In regard to the costs of suit itself, let

$$
\begin{aligned}
& \mathbf{a}=\text { plaintiffs' legal expenses; } \mathrm{a}>0 ; \\
& \mathbf{b}=\text { defendants' legal expenses; } \mathrm{b}>0 .
\end{aligned}
$$

(As noted, the possibility of settlement (whereby the legal expenses could in large part be avoided) will be considered subsequently.) The social welfare criterion is assumed to be the minimization of total social costs, which equal the sum of expected losses, prevention costs, and expected legal expenses. It is assumed that, legal expenses apart, social costs would be reduced by defendants' engaging in prevention activity, that is

$$
\text { (1) } \mathrm{x}+\mathrm{q} \dot{\ell}<\mathrm{p} \ell \text {. }
$$

This is the case of interest, for otherwise there is obviously no reason to employ a costly legal system to affect defendants' behavior.

Given these assumptions, there will be suit when

$$
\text { (2) } a<\ell \text {, }
$$

for if a plaintiff suffers a loss and brings suit, his net gain will be $\ell$ - a. Moreover, if (2) holds, then in (Nash) 
equilibrium defendants will engage in prevention activity; for if a defendant does so, his expected costs will be $x+q(l+b)$; if he does not, his expected costs will be $p(l+b)$; and from $(1)$ and $q<p$, it follows that

(3) $x+q(l+b)<p l+q b<p(l+b)$.

Consequently, total social costs will be 10

(4) $x+q l+q(a+b)$,

prevention costs plus expected losses plus expected legal expenses of plaintiffs and defendants.

If the inequality in (2) is reversed, then plaintiffs will not bring suit, ${ }^{11}$ so that in equilibrium defendants will not engage in prevention activity. Social costs will therefore be

(5) pl.

With regard to the social desirability of suit, the question is whether (4) is smaller than (5). Suit is socially desirable if

(6) $x+q l+q(a+b)<p l$, or, equivalently, if

(7) $a+b<(1 / q)[(p-q) l-x]$, or, again equivalently, if

(7') $q(a+b)<[(p-q) \&-x]$,

which says that the expected social cost of bringing suit is less than the expected social benefit, the reduction in losses net of prevention costs, $(p-q) l-x$. 
The private versus the social incentives to bring suit may now be compared using (2) and (7). 12 specifically, suit will occur when it ought not if (2) holds but the inequality in (7) is reversed. More generally, the following factors tend to make it more likely that there will be suit when it is not socially desirable: low legal expenses of plaintiffs, high legal expenses of defendants, high levels of loss, or low liability-induced reduction in expected losses net of prevention costs. ${ }^{13}$ on the other hand, the converse case, when it would be desirable for suit to occur but it does not, arises if (7) holds but the inequality in (2) is reversed; and the negative of the set of factors just mentioned--high legal expenses of plaintiff, low expenses of defendants, a low level of loss, a large reduction in net expected losses due to liability--tends to increase the likelihood that there will not be suit when it would be socially desirable. ${ }^{14}$ Additionally, it should be observed that there is no general tax, subsidy, or scheme for shifting legal fees which will induce parties to bring suit if and only if that is socially desirable. In other words, any method for altering plaintiffs' costs that does not depend on what would be the liability-induced reduction in losses in the particular situation under consideration will sometimes fail to result in a socially desirable outcome. 15

Numerical examples. Let us illustrate the two situations of interest: where suits are brought but that is socially 
undesirable; and where suits are not brought but it would be socially desirable that they be brought. In regard to the first type of situation, suppose that

$$
\begin{aligned}
\$ 1,000 & =\text { loss that plaintiffs might suffer, } \\
20 \%= & \begin{array}{l}
\text { probability of loss if defendants do not } \\
\text { engage in prevention activity, }
\end{array} \\
10 \%= & \begin{array}{l}
\text { probability of loss if defendants do engage } \\
\text { in prevention activity, }
\end{array} \\
\$ 50= & \text { cost of prevention activity, } \\
\$ 300= & \begin{array}{l}
\text { legal expense of suit for both plaintiffs } \\
\text { and defendants. }
\end{array}
\end{aligned}
$$

Since plaintiffs' legal expenses of $\$ 300$ are less than the $\$ 1,000$ in damages that they would receive if they bring suit, they will choose to bring suit. And since defendants would therefore incur expected liability costs of $20 \% \mathrm{x}$ $\$ 1,000=\$ 200$ if they do not engage in prevention activity but only $10 \% \times \mathrm{x} \$ 1,000=\$ 100$ if they do, they will find it worthwhile to bear costs of $\$ 50$ and to engage in prevention activity. Thus total social costs will be $\$ 210--p r e v e n t i o n$ costs of $\$ 50$ plus expected losses of $10 \% \times$ x $\$ 1,000$ plus expected legal expenses of plaintiffs and of defendants of $10 \% \times(\$ 300+\$ 300)$. However, if suits were not brought, total social costs would be only $\$ 200--t h e$ expected losses of $20 \% \times$ x $\$ 1,000$ (for defendants would not engage in prevention activity). Hence, that suits will be brought is socially undesirable. (Here, of course, the problem may be viewed as arising because plaintiffs do not take into account the fact that when they bring suit, defendants bear $\$ 300$ in legal expenses. ${ }^{16}$ ) 
Now, to illustrate the other situation, assume that

$$
\begin{aligned}
\$ 100 & =\text { loss that plaintiffs might suffer, } \\
10 \% & =\begin{array}{l}
\text { probability of loss if defendants do not engage } \\
\text { in prevention activity, }
\end{array} \\
1 \% & =\begin{array}{l}
\text { probability of loss if defendants do engage in } \\
\text { prevention activity, }
\end{array} \\
\$ 1 & =\text { cost of prevention activity, } \\
\$ 125= & \begin{array}{l}
\text { legal expense of suit for both plaintiffs and } \\
\text { defendants. }
\end{array}
\end{aligned}
$$

In this case, since plaintiffs' legal expenses of $\$ 125$ exceed the damages of $\$ 100$ that they would receive if they brought suit, plaintiffs will choose not to bring suit; and therefore defendants will have no motive to engage in prevention activity. Thus, total social costs will be $\$ 10--t h e$ expected losses of $10 \% \times \$ 100$. But if suits were brought, defendants would be induced to engage in prevention activity, for doing so would cost only $\$ 1$ and reduce their expected liability from $\$ 10$ to $\$ 1$. Hence, total social costs would be only $\$ 4.50--$ prevention costs of $\$ 1$ plus expected losses of $1 \% \times \$ 100$ plus expected legal expenses of $1 \% \times(\$ 125+$ $\$ 125)$. In consequence, it is indeed socially undesirable that suits will not be brought. ${ }^{17}$ (Here the problem may be interpreted as arising because plaintiffs do not take into account the general deterrent effect of suit as a benefit to themselves.)

2. Extension of the model: the possibility of settlement The essential nature of the comparison between the private and the social incentive to make use of the legal 
system is not changed if account is taken of the possibility of settlement. However, it will be seen that allowing for settlement makes it more likely that suit, or rather the threat of suit, is socially desirable. Let us assume that a plaintiff will press a $\operatorname{claim}^{18}$ if and only if he would actually be willing to bring suit; and that he will then decide to settle with the defendant if and on'y if there exists a settlement which both he and the defendant would prefer to going ahead with suit. Further, let

C = plaintiff' expenses in reaching a settlement; c > $\mathrm{O}$;

d $=$ defendants' expenses in reaching a settlement; d > O;

assume that the costs of settlement are less than those of suit,

(13)

$$
c+d<a+b
$$

and let

$$
\text { s }=\text { settlement amount. }
$$

Under these assumptions, plaintiffs will press claims in the same circumstances as before, when (2) holds, and then will settle for an amount satisfying ${ }^{19}$

$$
\ell+c-a<s<\ell+b-d \text {. }
$$

Thus, if (2) holds, and presuming defendarts will choose to engage in prevention activity, 20 total social costs will be given by

$$
\text { (15) } x+q l+q(c+d)
$$


rather than by (4); and if the inequality in (2) is reversed, the situation will be as before, with social costs given by (5). Consequently, pressing claims is socially desirable if (16)

$$
x+q l+q(c+d)<p l,
$$

or, equivalently, if

$$
c+d<(1 / q)[(p-q) 2-x]
$$

here the social costs of the pressing of claims are the costs of settlement, $c+d$, rather than the costs of suit, $a+b$, as in (7). Using (2) and (17), the private and social incentives to press claims can be compared much as before and analogous statements can be made. The main difference is that, as noted, it is more likely that the pressing of claims is socially desirable than that suit was socially desirable ((17) holds more often than (7) since $c+d<a+b)$.

\section{Concluding comment}

It should be clear that the basic points made here about possible divergence between the private and social incentives to bring suit would apply quite generally, in respect to a more realistic description of the social costs and the social benefits of use of the legal system. ${ }^{21}$ And given this broad interpretation, one might view various social efforts to promote or subsidize suit (availability of the class action; establishment of small claims courts) as social solutions to problems of otherwise insufficient private motives to bring suit. Similarly one might see 
social attempts to reduce the volume of suits, passage of statutes to circumvent the legal system (automobile no-fault, workers' compensation) and, perhaps, the notion that society is on balance too litigious as reflecting problems of excessive private incentives to bring suit. 
Footnotes

*Assistant Professor, Harvard Law School. I wish to thank Frank Easterbrook, Mitch Polinsky and David Shapiro for comments and the National science Foundation (grants SOC-76-20862 and SES 8014208) for financial support.

1. Ordover (1978) also studies a model of legal liability and costly litigation, and makes several observations that bear on the question of concern to us; but the main point and the focus of his paper is different; see note 13 below.

2. Henceforth, "potential plaintiffs" and "potential defendants" will be referred to simply as "plaintiffs" and "defendants" even though a "defendant" might not in fact cause a loss and even though, if he does, the "plaintiff" might choose not to sue.

3. For simplicity, public expenses connected with operation of the courts are not considered in the model.

4. This statement will be qualified when the possibility of settlement is considered.

5. It will be seen that in the model the externality is due solely to the fact that bringing suit raises the likelihood that defendants will be liable. The externality is thus logically distinct from that associated with creation of precedent, which is not considered in the model. 
6. Polinsky (1980) makes related points in examining the issue of public versus private enforcement of fines.

7. It will be seen that the model to be analyzed is of a discrete rather than of a continuous nature. The discrete model is presented because the results in a continuous version of the model, while in essence those of the discrete model, cannot be expressed in as simple a form as in the discrete model. (The principal complication in the continuous model arises from the necessity to consider the private vs. the social incentive to bring suit for each possible level of loss.)

8. Prevention activity should be broadly interpreted as taking care to fulfill a contractual obligation, to prevent accidents, etc.

9. In other words, the defendant's (strict) liability for loss is assumed. But this should not bother the reader. In a previous version of the present paper, fault-based liability was also considered, and the qualitative nature of the results was unchanged, provided that the model of such liability allowed for the possibility that parties would sometimes be found at fault. (In an over simple model not allowing for such possibility, all parties would be induced to act so that they would never be found at fault, the consequence being 
that suits would never be worthwhile bringing; thus, the legal system would turn out to be costless.)

10. For simplicity, these will be written on a per defendant basis.

11. We will not bother to discuss the case when $a=\ell$ and plaintiffs are indifferent whether or not to bring suit.

12. And observe that the informal comparison made in the introduction between private and social costs and between private and social benefits can now be seen explicitly: from the left-hand sides of (2) and (7), it is evident that the private cost a is less than the social cost $a+b ;$ and from the right-hand sides, that the private benefit $\&$ could be either less than or greater than the quantity $1 / q[(p-q) \ell-x]$

13. A precise statement is as follows. There will be suit when that is socially undesirable (i) if, given that $b>(1 / q)[(p-q) \ell-x]$, the plaintiff's legal expense a is sufficiently low; (ii) if, given that $a<\ell$, the defendant's legal expense b is sufficiently high; (iii) if, given that $a+b>(1 / q)[(p-q) a-x]$, the loss $\&$ is high enough to exceed a (but not by so much as to make suit socially worthwhile); (iv) if, given that $a<\ell$, the quantity $(1 / q)[(p-q) \ell-x]$ is sufficiently low (as when $q \rightarrow p$ ). 
14. The point of the comparison that has been made between the social and the private incentive to bring suit may be contrasted with that of ordover (1978), which examines the implications of costly litigation when potential plaintiffs do not know whether the particular parties they contemplate suing would be found liable. Under.this assumption, plaintiffs may have an inadequate incentive to bring suit. We chose not to analyze ordover's assumption because our goal was to abstract from issues concerning imperfect information.

15. If a plaintiff's costs do not depend on all the variables $2, p, q$, and $x$, it is clear that he will not be induced to bring suit if and only if (7) holds. For instance, making the plaintiff bear the full social costs of suit, $a+b$, would not be satisfactory, for the plaintiff would compare this to $\ell$, which could be either higher or lower than $(1 / q)[(p-q) 2-x]$.

16. In other words, the expected social cost of suit is $\$ 300+\$ 300=\$ 600$, and this exceeds the social benefits due to deterrence.

17. Notice that the statement is true even though the $\$ 250$ total legal expenses of a suit substantially exceed the $\$ 100$ amount at stake. But this is not a paradox; suit is socially worthwhile because of its deterrent effect. 
18. "Pressing a claim" should be interpreted either as threatening legal proceedings or as actually beginning them, but not as going ahead to trial.

19. This follows from the facts that for the plaintiff to be made better off by settling, $s-c>\ell-a$ must hold, and for the defendant to be made better off, $s+d<\ell+b$ must hold. It should also be noted that the reason there is always settlement is that we have not allowed (because it is tangential to our purposes) for such possibilities as that the plaintiff and the defendant might have differing assessments of the likelihood of prevailing or of the size of the judgment.

20. A sufficient condition for this is that $s+d \geqq \ell$.

21. Included among the social costs would, as previously remarked, be the expenses involved in operating the courts, and among the social benefits, the creation of precedent. On the latter, see Landes and Posner (1979).

\section{References}

Landes, W. and R. Posner, "Adjudication as a Private Good." Journal of Legal Studies, Vol. 8 (March 1979), pp. 235-284. Ordover, J., "Costly Litigation in the Model of Single Activity Accidents." Journal of Legal Studies, Vol. 7 (June 1978), pp. 243-262. 
Polinsky, A.M., "Private versus Public Enforcement of Fines." Journal of Legal Studies, Vol. 9 (January 1980), pp. 105-128. 